\title{
Introduction: sketches of a conceptual history of epigenesis
}

\author{
Antonine Nicoglou' ${ }^{1}$ Charles T. Wolfe ${ }^{2}$
}

Received: 16 March 2018 / Accepted: 17 October 2018 / Published online: 23 October 2018 (C) Springer Nature Switzerland AG 2018

\begin{abstract}
This is an introduction to a collection of articles on the conceptual history of epigenesis, from Aristotle to Harvey, Cavendish, Kant and Erasmus Darwin, moving into nineteenth-century biology with Wolff, Blumenbach and His, and onto the twentieth century and current issues, with Waddington and epigenetics. The purpose of the topical collection is to emphasize how epigenesis marks the point of intersection of a theory of biological development and a (philosophical) theory of active matter. We also wish to show that the concept of epigenesis existed prior to biological theorization and that it continues to permeate thinking about development in recent biological debates.
\end{abstract}

Keywords Epigenesis $\cdot$ Epigenetics $\cdot$ Embryology $\cdot$ Matter theory $\cdot$ Vitalism

What does it mean to investigate the conceptual history of a scientific term such as epigenesis? Epigenesis is the embryological theory according to which "organs [...] are progressively formed from, or emerge from, an originally undifferentiated, homogenous [material]" (Smith 1976, p. 264). Aristotle (384-322 BC) is often seen as the first philosopher who defined epigenesis, despite the fact that the term does not appear at all in his work. In our topical collection, Ina Goy asks if it makes sense to ascribe such a view to an ancient thinker given that epigenesis is in some basic sense a necessarily 'modern' notion (Goy 2018). Aristotle's great successors in the sixteenth and seventeenth centuries, starting with William Harvey (1578-1657), already proposed revised and expanded definitions compared to

Antonine Nicoglou

antoninenico@gmail.com

1 CRPMS \& IJM, Sorbonne Paris Cité \& IHPST Paris, Paris, France

2 Ghent University, Ghent, Belgium 
what has been attributed to Aristotle (see in our topical collection, in addition to Goy's essay, Benjamin Goldberg's discussion of Harvey: Goldberg 2017). For Aristotle, epigenesis could be seen as a general process that explained the development of a form. For Harvey it means, to abbreviate his analysis considerably, the "addition of the parts that successively arise" or "the superaddition of parts", "the form is due to the potency of a preexisting material" (Harvey 1847, ex. 51, 45 p. 372, p. 335), although Harvey actually distinguishes, within the general theme of embryos emerging out a process of purely material complexification, between metamorphosis and epigenesis ${ }^{1}$ (metamorphosis being, for Harvey, the process by which the whole material contained in the embryo is transformed).

While epigenesis came in the seventeenth and eighteenth centuries to be seen as a 'materialist' or 'materialism-friendly' concept linked to generation (e.g. Samuel Clarke negatively and Denis Diderot positively), as opposed to preformation, such a vision would run into major obstacles within Harvey's work, given that in his analysis of generation (if not in his even more celebrated analysis of circulation) he is a self-proclaimed Aristotelian. In an Aristotelian theory of generation, epigenesis implies that the unformed (or "unpreformed," as Jason Scott Robert has it; see Robert 2004, p. 36) organismal substance takes up a form that is in it potentially. Harvey was read and eagerly appropriated by materialistically inclined thinkers in the next century, but one must not lose sight of his own Aristotelianism. However, since our interest here is not Harvey in and of himself, but the shifting fortunes of the epigenesis concept, it is important to note that very soon afterwards, 'epigenesis' came to designate an intersection between a theory of biological development and a theory of the vital potentiality of matter to self-organize.

As early as Francis Glisson (1598-1677), we find epigenesis associated with a metaphysics of life, a theory of innate potentialities or 'appetites' in matter (Giglioni 2008; Wolfe 2017a). The way epigenesis is in fact located in between embryology and metaphysics is also apparent in Samuel Clarke's attacks on Anthony Collins, early in the next century: "It being as impossible that the organized Body of a Chicken should by the power of any Mechanical Motions be formed out of the unorganized Matter of an Egg; as that the Sun, Moon and Stars, should by mere Mechanism arise out of a Chaos" (Clarke 1707, in Clarke 1978, III, p. 789). In her contribution to our topical collection, Angela Ferraro (Ferraro 2016) discusses littleknown medical and philosophical treatises in favor of epigenesis, from the end of the seventeenth century to the $1720 \mathrm{~s}$, illustrating early connections between materialism and epigenesis, prior to well-known statements from authors such as Buffon, Maupertuis and Diderot in the mid-eighteenth century (on epigenesis and materialism in the later period see Schmitt 2014; Wolfe 2014). By the early twentieth century, epigenetic notions (including the legitimate or illegitimate progeny of epigenesis, epigenetics, discussed in the essays by Antonine Nicoglou on Waddington, and Karola Stotz and Paul Griffiths on epigenetics per se) seem to be fellow-travellers of vitalism.

\footnotetext{
${ }^{1}$ It is worth noting that some scholars such as Bowler speak of all such positions as 'metamorphosis' in any case (Bowler 1971, p. 223).
} 
Further metaphysical implications of epigenesis are explored by Goldberg, whose essay discusses William Harvey's, but also Margaret Cavendish's treatment of the topic, and Boris Demarest, who delves into Kant's analysis of epigenesis and seeks to show how the German philosopher shifted the ground of the epigenesis-preformationism debate. In contrast to this Kantian focus (and the fixation on self-organization that often comes with it), Amanda Goldstein's essay seeks to reconstruct an alternative, "Romantic genealogy of the biological present" in which Jean-Baptiste Lamarck and Erasmus Darwin come to the fore (Goldstein 2017; see also MüllerSievers 1997).

From the theoretical point of view, preformation, understood as the theory opposed to epigenesis, only appeared in the seventeenth century with the work of Marcello Malpighi (1628-1694) and his observations with a microscope, through which he thought he could see miniaturized organs in the egg or even in the semen (Adelmann 1966; Bertoloni Meli 2011). One can say that the debate between epigenesis and preformationism became "the central problem of embryology in the early modern period, at the moment when preformation gained new plausibility as a result of microscopic research on the primordia of living beings" (Smith 2011, p. 170). After a long period during which the theory of epigenesis was rejected in favor of preformation, at the end of the eighteenth century the principle of epigenesis reappeared with the emergence of descriptive embryology and the work of Caspar Friedrich Wolff (1733-1794). As Dupont describes it, in Wolff's work, "formation operates through a series of distinct creations of systems (nervous, muscular, digestive, etc.), rather than through isolated organs, each of them forming a relatively autonomous whole" (Dupont 2003, p. 50). Here, embryological experiments are bound up with philosophical and theoretical interpretations, including in the WolffBlumenbach debate in the early nineteenth century. By the time of Wilhelm His' (1831-1904) work extending the Entwicklungsmechanik paradigm (discussed in the essay by Jean-Claude Dupont 2017), epigenesis had become a wholly experimental endeavor-although at the same time, we should be cautious with regard to facile oppositions between 'metaphysical' and 'experimental' dimensions of the epigenesis concept. From the early modern context to Waddington in the mid-twentieth century, 'poiesis', 'surrounding forces', and a specific conception of 'causality' are all parts of the metaphysical apprehension of embryogenesis. Indeed, for most of the authors referring to the idea of epigenesis, experiments become central to prove their intuitions. However, the concepts they use remain highly linked to a metaphysical background. For instance, both the notion of forces and causality refer to their complex uses in philosophy and not yet to a mechanistic causality as it will be the case from the mid-twentieth century.

The tension between epigenesis and preformationism as theories, evolves from the eighteenth century onwards, as has been studied in increasingly specialized scholarship (Needham 2015; Gould 1977; Roe 1979, 1981, 2003; Robert 2004; Maienschein 2005; Detlefsen 2006; Laubichler and Maienschein 2009; Müller-Wille and Rheinberger 2012). Epigenesis was understood as the idea that there was no pre-established organization whereas with preformationism, the parts were already determined. While the preformationists finally took over in the debate, more than a century later, the embryologists Hans Driesch (1867-1941) and Oscar Hertwig 
(1849-1922) influenced by the cell theory argued in favor of the theory of epigenesis. In his famous book of 1977, entitled Ontogeny and Phylogeny, Gould argued that one should use the notion of neo-epigenesis to describe their theories since they have little or almost nothing to do with C.F. Wolff's eighteenth century use of the notion of epigenesis.

Joseph Needham was certainly right when he argued in 1934, in the first edition of his history of embryology (revised edition, 1959), that the history of the opposition between epigenesis and preformationism was almost synonymous with the history of embryology (Needham 2015). However, scholarship in the past decades has increasingly emphasized that the meaning of each of these notions has broadly changed in the course of centuries, even if at times it is claimed that "Epigenesis has triumphed in modern developmental biology since the zygote is undifferentiated, and different types of cells, those of nerves, muscles, and such, develop only gradually as a result of conception" (Smith 2011, p. 170). In fact, in an instance of theory and experiment in interaction, the new methods and techniques applied in the field of embryology have progressively, but also vastly contributed to modify the way the different scientists have understood and defined those two theoretical options. In addition to this, the interest in embryology has progressively moved towards issues in genetics from the early twentieth century on.

In the early $1930 \mathrm{~s}$, Conrad Hall Waddington (1905-1975), who was interested in both embryology and genetics (he had worked with two Nobel Prize winners, Hans Spemann, the expert of the induction process in embryology and with Thomas Hunt Morgan, who had discovered the role that chromosomes play in heredity), proposed the notion of epigenetics to describe the developmental processes to produce phenotypes from genotypes (Peterson 2017; Nicoglou and Merlin 2017; Nicoglou 2018). Waddington's first idea was to reexamine epigenesis (understood as developmental process) by including genetical data. But the notion of epigenetics evolved in Waddington's mind and its definition is nowadays the subject of arduous debates in the scientific community (Ptashne 2007; Bird 2007). It is one of the reasons why anybody who deals with epigenetics today or sixty years ago is probably not talking about epigenesis in any of its older senses (Griffiths and Stotz 2013; Stotz and Griffiths 2016; Willer 2010).

Work on epigenesis has taken different forms in recent decades. Sometimes it is studied in strictly historical terms, as in the studies by Needham, Gould, Roe and other, or as part of a new focus on generation in early modern philosophy (Smith ed. 2006) or in the history of embryology (from Needham to Maienschein). Sometimes the dominant influence is contemporary theoretical biology, as in the 2002 volume From Epigenesis to Epigenetics (Van Speybroek, Van de Vijver, and de Waele, eds. 2002). In this topical collection we have sought, without claiming to reach some purported 'total' narrative, to revisit the concept, scientific contexts and metaphysical implications or foundations of epigenesis. The papers included here go from Aristotle and especially, the early modern period, to the nineteenth century (touching on theological dimensions, matter-theory and materialism), as well as confronting epigenesis with genetics and its new challenger, epigenetics. A recurrent theme, sometimes implicit, sometimes explicit, is that epigenesis implies that matter has the power to self-organize, beyond the confines of embryological theory; in this 
way, ideas of active matter even find echoes in the discourse of molecular genetics, in ways that would appeal to current New Materialists (Wolfe 2017b), if not to the 'working molecular biologist' or her reductionist philosophical commentator.

Acknowledgements Thanks to Jean-Claude Dupont and Staffan Müller-Wille for their input on an earlier version of this introduction.

\section{References}

Adelmann, H. B. (1966). Marcello Malpighi and the evolution of embryology. 5 vols. Ithaca: Cornell University Press.

Bertoloni Meli, D. (2011). Mechanism, experiment, disease: Marcello Malpighi and seventeenth-century anatomy. Baltimore: The Johns Hopkins University Press.

Bird, A. (2007). Perceptions of epigenetics. Nature, 447(7143), 396-398.

Bowler, P. J. (1971). Preformation and pre-existence in the seventeenth century: A brief analysis. Journal of the History of Biology, 4(2), 221-244.

Clarke, S. (1978). Letter to Mr. Dodwell [for Anthony Collins]=Second Defence of the Immateriality and Immortality of the Soul (1707), in Clarke, The Works of Samuel Clarke, 4 vols., 1738, vol. III; reprint, New York: Garland.

Demarest, B. (2017). Kant's epigenesis: Specificity and developmental constraints. History and Philosophy of the Life Sciences. https://doi.org/10.1007/s40656-017-0129-2.

Detlefsen, K. (2006). Explanation and demonstration in the Haller-Wolff debate. In J. E. H. Smith (Ed.), The problem of animal generation in early modern philosophy (pp. 235-261). Cambridge: Cambridge University Press.

Dupont, J.-C. (2017). Wilhelm His and mechanistic approaches to development at the time of Entwicklungsmechanik. History and Philosophy of the Life Sciences. https://doi.org/10.1007/s4065 6-017-0148-z.

Dupont, J. C., \& Perrin, J.-L. (2003). Caspar Friedrich Wolff. De formatione intestinorum. La formation des intestins (pp. 1768-1769). Turnhout: Brepols.

Ferraro, A. (2016). Theorizing epigenesis in a time of preexistence: From the end of the seventeenth century to the 1720 s. History and Philosophy of the Life Sciences. https://doi.org/10.1007/s4065 6-016-0115-0.

Giglioni, G. (2008). What ever happened to Francis Glisson? Albrecht Haller and the fate of eighteenthcentury irritability. Science in Context, 21, 465-493.

Goldberg, B. (2017). Epigenesis and the rationality of nature in William Harvey and Margaret Cavendish. History and Philosophy of the Life Sciences. https://doi.org/10.1007/s40656-017-0134-5.

Goldstein, A. J. (2017). Epigenesis by experience: Romantic empiricism and non-kantian biology. History and Philosophy of the Life Sciences. https://doi.org/10.1007/s40656-017-0168-8.

Gould, S. J. (1977). Ontogeny and Phylogeny. Cambridge: Harvard University Press.

Goy, I. (2018). Was Aristotle the 'father' of the epigenesis doctrine? History and Philosophy of the Life Sciences. https://doi.org/10.1007/s40656-018-0193-2.

Griffiths, P., \& Stotz, K. (2013). Genetics and philosophy: An introduction. Cambridge: Cambridge University Press.

Harvey, W. (1651/1847). Exercitationes de Generatione Animalium..., In The works of William Harvey, (W. Robert, Trans.). London: Sydenham Society.

Laubichler, M., \& Maienschein, J. (2009). From embryology to evo-devo: A history of developmental evolution. Cambridge: MIT Press.

Maienschein, J. (2005). Epigenesis and Preformationism. In E. N. Zalta (Ed.), The stanford encyclopedia of philosophy. Spring 2017 Edition. https://plato.stanford.edu/archives/spr2017/entries/epigenesis/.

Müller-Sievers, H. (1997). Self-Generation. Biology, Philosophy, and Literature Around 1800. Stanford: Stanford University Press.

Müller-Wille, S., \& Rheinberger, H.-J. (Eds.). (2012). A cultural history of heredity. Chicago: University of Chicago Press. 
Needham, J. \& Hugues, A. (2015). A history of embryology. Facsimile ed. 1 vol. [1959] 2nd edn. Cambridge: Cambridge University Press.

Nicoglou, A. (2018). Waddington's epigenetics or the pictorial meetings of development and genetics. History and Philosophy of the Life Sciences. https://doi.org/10.1007/s40656-018-0228-8.

Nicoglou, A., \& Merlin, F. (2017). Epigenetics: a way to bridge the gap between biological fields. Studies in History and Philosophy of Science Part C: Studies in History and Philosophy of Biological and Biomedical Sciences, 66, 73-82.

Peterson, E. L. (2017). The life organic: The theoretical biology club and the roots of epigenetics. Pittsburgh: University of Pittsburgh Press.

Ptashne, M. (2007). On the use of the word 'epigenetic'. Current Biology, 17(7), R233-R236.

Robert, J. Scott. (2004). Embryology, epigenesis and evolution: Taking development seriously. Cambridge: Cambridge University Press.

Roe, S. A. (1979). Rationalism and embryology: Caspar Friedrich Wolff's theory of epigenesis. Journal of the History of Biology, 12(1), 1-43.

Roe, S. A. (1981). Matter, life, and generation: Eighteenth-Century embryology and the Haller-Wolff debate. (Reprinted from 2003, Cambridge: Cambridge University Press).

Schmitt, S. (2014). Mécanisme et épigenèse: les conceptions de Bourguet et de Maupertuis sur la génération. Dix-huitième siècle, 46(1), 477-499.

Smith, C. U. M. (1976). The problem of life: An essay in the origins of biological thought. New York: Wiley.

Smith, J. E. H. (Ed.). (2006). The problem of animal generation in early modern philosophy. Cambridge: Cambridge University Press.

Smith, J. E. H. (2011). Divine Machines. Leibniz and the sciences of life. Princeton: Princeton University Press.

Stotz, K., \& Griffiths, P. (2016). Epigenetics: Ambiguities and implications. History and Philosophy of the Life Sciences. https://doi.org/10.1007/s40656-016-0121-2.

Van Speybroeck, L., De Waele, D., \& Van De Vijver, G. (2002). Theories in early embryology. Close connections between epigenesis, preformationism, and self-organization. Annals of the New York Academy of Sciences, 981, 7-49.

Willer, S. (2010). 'Epigenesis' in epigenetics: Scientific knowledge, concepts, and words. In A. Barahona, E. Suarez-Díaz, \& H.-J. Rheinberger (Eds.), The hereditary hourglass: Genetics and epigenetics 1868-2000, Max-Planck-Institut für Wissenschaftsgeschichte. (Preprint from 392, pp. 13-21, Berlin: Max-Planck-Institut für Wissenschaftsgeschichte)

Wolfe, C. T. (2014). Epigenesis as Spinozism in Diderot's biological project. In O. Nachtomy \& J. E. H. Smith (Eds.), The life sciences in early modern philosophy (pp. 181-201). Oxford: Oxford University Press.

Wolfe, C.T. (2017a). Varieties of vital materialism. In S. Ellenzweig and J. Zammito, eds., The new politics of materialism. history, philosophy, science (pp. 44-65). London: Routledge.

Wolfe, C. T. (2017b). Materialism new and old. Antropologia Experimental, 17, 215-224. 